\title{
ANALISIS BREAK EVEN POINT SEBAGAI DASAR PERENCANAAN LABA PADA RUMAH MAKAN SEDERHANA
}

\author{
Oleh \\ Husin', Fitriaman', Linda Astika ${ }^{3}$
Jurusan Akuntansi Fakultas Ekonomi dan Bisnis Universitas Halu Oleo Kendari Sulawesi Tenggara

\begin{abstract}
ABSTRAK
Penelitian ini dilakukan dengan tujuan (1) mengetahui penjualan yang harus dipertahankan RM. Sederhana agar tidak mengalami kerugian (2) mengetahui jumlah penjualan minimal yang harus dicapai pada jumlah laba yang direncanakan RM. Sederhana. Penelitian ini menggunakan pendekatan penelitian kualitatif. Penelitian kualitatif adalah dengan menekankan analisisnya pada proses penyimpulan komparasi serta pada analisis terhadap dinamika hubungan fenomena yang diamati dengan menggunakan logika ilmiah. Teknik pengumpulan data menggunakan pengumpulan data melalui dokiumentasi. Analisis data menggunakan rumus titik impas dan margin keamanan.

RM. Sederhana adalah rumah makan yang menjual makanan khas padang. Hasil analisis sebagai berikut: (1) Titik impas pada tahun 2017 yaitu Rp 169.170.212,76. Titik impas pada tahun 2018 yaitu Rp 186.122.580,64. Titik impas pada tahun 2019 yaitu Rp 198.024.706,52. (2) Margin keamanan atau margin of safety tahun 2017 yaitu $60 \%$ yang berarti bahwa pada tingkat penjualan yang struktur biaya yang ada, jumlah maksimum penurunan target pendapatan penjualan yang menyebabkan perusahaan mengalami kerugian adalah Rp252.450.000,-. Margin keamanan atau margin of safety tahun 2018 yaitu $62 \%$ yang berarti bahwa pada tingkat penjualan yang struktur biaya yang ada, jumlah maksimum penurunan target pendapatan penjualan yang menyebabkan perusahaan mengalami kerugian adalah Rp307.507.600,-. Margin keamanan atau margin of safety tahun 2019 yaitu 55\% yang berarti bahwa pada tingkat penjualan yang struktur biaya yang ada, jumlah maksimum penurunan target pendapatan penjualan yang menyebabkan perusahaan mengalami kerugian adalah Rp244.250.462,5,-. Estimasi perencanaan laba RM. Sederhana pada tahun 2020 adalah: (1) Titik impas RM. Sederhana pada tahun 2020 dihitung Rp247.530.882,-. Titik impas RM. Sederhana pada tahun 2021 dihitung Rp367.303.890,-- (2) Margin keamanan tahun 2020 sebesar 55\%, jumlah maksimum penurunan target pendapatan penjualan yang tidak menyebabkan perusahaan mengalami kerugian adalah Rp305.313.007,-. Margin keamanan tahun 2021 sebesar 56\%, jumlah maksimum penurunan target pendapatan penjualan yang tidak menyebabkan perusahaan mengalami kerugian adalah Rp466.296.336,-. (3) Tahun 2020 laba yang direncanakan untuk memperoleh keuntungan sebesar $25 \%$ dari penjualan, maka perusahaan harus dapat melakukan penjualan sebesar Rp339.893.152,-- Tahun 2019 laba yang direncanakan untuk memperoleh keuntungan sebesar 50\% dari penjualan, maka perusahaan harus dapat melakukan penjualan sebesar Rp517.564.572,-.
\end{abstract}

Kata Kunci: Titik Impas dan Perencanaan Laba.

\section{ABSTRACT}

This research was conducted with the aim of (1) knowing the sales that must be maintained by RM. Simple so as not to experience a loss (2) knowing the minimum number of sales that must be achieved at the amount of profit planned for RM. Simple. This study uses a qualitative research approach. Qualitative research is to emphasize its analysis in 
Jurnal Akuntansi dan Keuangan (JAK)

Volume 6, No. 1 Februari Tahun 2021

Page: $56-73$

http://ojs.uho.ac.id/index.php/iak-uho/issue/archive

e-ISSN: 2088-4656

the process of concluding comparisons as well as on the analysis of the dynamics of the observed phenomena using scientific logic. Data collection techniques use data collection through documentation. Data analysis using the break-even point formula and safety margin.

RM. Simple is a restaurant that sells typical Padang food. The results of the analysis are as follows: (1) The break-even point in 2017 was IDR 169,170,212.76. The break-even point in 2018 is IDR 186,122,580.64. The break-even point in 2019 is IDR 198,024,706.52. (2) The safety margin or margin of safety in 2017 is $60 \%$, which means that at the level of sales with the existing cost structure, the maximum amount of reduction in the sales revenue target that causes the company to suffer losses is IDR 252,450,000. The safety margin or margin of safety in 2018 is 62\%, which means that at the level of sales with the existing cost structure, the maximum amount of decline in sales revenue targets that causes the company to suffer losses is IDR 307,507,600. The safety margin or margin of safety in 2019 is 55\%, which means that at the level of sales with the existing cost structure, the maximum amount of decline in sales revenue targets that causes the company to suffer losses is IDR 244,250,462.5. RM profit planning estimate. The modest in 2020 are: (1) RM break-even point. Simple in 2020 is calculated as IDR 247,530,882. Break-even point RM. Simple in 2021 is calculated as IDR 367,303,890. (2) The safety margin in 2020 is $55 \%$, the maximum amount of a decrease in the sales revenue target that does not cause the company to suffer a loss is IDR 305,313,007. The security margin in 2021 is 56\%, the maximum amount of the decline in sales revenue target that does not cause the company to suffer a loss is IDR 466,296,336. (3) In 2020 profit which is planned to gain $25 \%$ of sales, the company must be able to make sales of IDR 339,893,152. In 2019 the profit is planned to get a profit of $50 \%$ from sales, so the company must be able to make sales of IDR $517,564,572$.

Keywords: Break-even Point and Profit Planning.

\section{PENDAHULUAN}

Saat ini persaingan bisnis di Indonesia sangatlah ketat. Tidak heran jika banyak perusahaan yang tumbuh, berkembang, dan sukses. Tetapi ada juga yang mengalami penurunan sampai gulung tikar. Untuk mengatasi masalah-masalah yang timbul dalam persaingan bisnis, salah satu yang dapat dilakukan perusahaan yaitu harus mampu mengendalikan operasionalnya dengan baik. Karena jika terjadi kesalahan dalam mengambil keputusan, akan mengakibatkan ketidakmampuan perusahaan untuk ikut dalam persaingan bisnis yang semakin ketat.

Pada dasarnya manajemen harus memutuskan bagaimana mengelola sumber daya ekonomi sesuai dengan tujuan perusahaan.Tujuan sebuah perusahaan adalah untuk memperoleh keuntungan atau laba yang dapat dipergunakan untuk kelangsungan hidup. Mendapatkan keuntungan atau laba dan besar kecilnya laba sering menjadi ukuran kesuksesan suatu manajemen perusahaan. Hal tersebut didukung oleh kemampuan manajemen di dalam melihat kemungkinan dan kesempatan dimasa yang akan datang. Bagi perusahaan yang memiliki aktifitas operasional yang rumit dan kompleks senantiasa dihadapkan pada masalah manajemen sumber daya agar bisa dimanfaatkan secara efektif dan efisien. Dalam upaya mengatasi masalah itu manajemen harus terampil dan mampu bekerja secara cermat.

Ekonomi yang pasang surut akhir-akhir ini mengakibatkan harga bahan baku serta daya beli masyarakat berubah-ubah. Hal ini memberikan pengaruh bagi perusahaan dalam menentukan harga dan volume produksi. Sehingga kemampuan manajemen dalam menerapkan strategi perusahaan harus memadai untuk menghadapi persaingan dengan 
perusahaan sejenis agar perusahaan dapat tetap berjalan dan mampu menghasilkan keuntungan yang maksimal.

Secara umum laporan keuangan disajikan dengan tujuan untuk menyampaikan informasi tentang kondisi keuangan perusahaan pada periode tertentu kepada para pemangku kepentingan. Para pengguna laporan keuangan menggunakan informasi dalam laporan keuangan sebagai dasar dalam memilih alternatif penggunaan sumber daya perusahaan yang terbatas.

Dalam laporan keuangan perlu diperhatikan bahwa laporan laba rugi yang memuat tentang biaya-biaya yang dikeluarkan perusahaan. Biaya adalah pengorbanan sumber ekonomis yang diukur dalam satuan mata uang yang telah terjadi atau kemungkinan yang terjadi dalam mencapai tujuan tertentu (to secure benefit).

Perencanaan laba memerlukan alat bantu berupa analisis biaya volume laba. Biaya, volume, dan laba merupakan tiga elemen pokok dalam penyusunan laporan laba rugi. Dalam menjalankan kegiatan operasinya, sebuah perusahaan manjemen akan berupaya memperoleh dan mengalokasikan sumber daya dengan cara yang paling murah dari segi biaya dan paling banyak memberikan manfaat dalam pencapaian tujuan perusahaan.

Pemahaman mengenai aplikasi konsep biaya, volume, dan laba dapat digunakan oleh manajemen sebagai dasar untuk merencanakan komposisi tingkat biaya, volume, dan laba dapat digunakan oleh manajemen sebagai dasar untuk merencanakan komposisi tingkat biaya, volume, dan laba yang menguntungkan. Sebagai komponen yang saling berhubungan komposisinya harus berada pada titik yang optimal. Studi mengenai hubungan antara pendapatan, biaya, dan laba kemudian dalam buku ini dikenal sebagai analisis hubungan biaya volume laba.

Pengetahuan dasar yang sangat menentukan dalam analisis biaya, volume, dan laba adalah pemahaman tentang penyusunan laporan laba-rugi dengan menggunakan pendekatan variable costing. Pendekatan ini menghasilkan suatu model laporan laba rugi dimana biaya di klasifikasikan menurut perilakunya. Agar lebih informatif, maka sebaiknya laporan laba-rugi diuraikan dalam bentuk laporan penjualan secara total dan penjualan per unit. Selain itu diperlukan juga hasil analisis vertikal yang menunjukan persentase biaya variabel dan rasio margin kontribusi dari nilai penjualan.

Salah satu teknik analisis biaya volume laba adalah analisis break even point atau analisis titik impas. Analisis break even point sering digunakan dalam perencanaan keuangan. Namun rumus ini juga dapat digunakan dalam hal lain misalnya analisis laporan keuangan. Untuk mengetahui perencanaan laba pada suatu perusahaan, maka dapat dilakukan juga dengan analisis titik impas. Analisis titik impas adalah suatu cara atau teknik yang digunakan oleh seorang manajer suatu perusahaan untuk mengetahui jumlah penjualan dan jumlah produksi suatu perusahaan yang bersangkutan tidak mengalami untung dan rugi. Dengan kata lain bahwa titik impas adalah suatu keadaan dimana suatu perusahaan yang pendapatan penjualannya sama dengan total biaya, atau besarnya kontribusi margin sama dengan total biaya tetap.

Kondisi Rumah Makan Sedehana untuk tahun 2018-2019 mengalami perubahan pada pendapatan, beban dan laba rugi. Rumah Makan Sedehana adalah bergerak dalam bidang usaha restoran yang menjual makanan. Salah satu unit bisnis utama yang dikembangkan di restoran ini adalah unit bisnis buffet. Unit bisnis ini menjual produk berupa makanan prasmanan yang di desain dan disiapkan untuk acara-acara formal seperti meeting, ulang tahun, maupun pertemuan resmi lainnya.

Berikut adalah perkembangan pendapatan, beban dan laba rugi perusahaan untuk periode akuntansi 2017-2019. 
Jurnal Akuntansi dan Keuangan (JAK)

Volume 6, No. 1 Februari Tahun 2021

Page: $56-73$

http://ojs.uho.ac.id/index.php/iak-uho/issue/archive

e-ISSN: 2088-4656

Tabel 1.1Anggaran Biaya Tahun 2017, 2018, dan 2019 Rumah Makan Sederhana

\begin{tabular}{|c|c|c|c|}
\hline Jenis Biaya & 2017 & 2018 & 2019 \\
\hline 1. Biaya Non Produksi & & & \\
\hline a. Biaya Gaji Administrasi & $\operatorname{Rp} 1.000 .000$ & 1.000 .000 & 1.000 .000 \\
\hline b. Biaya Alat Tulis Kantor & 890.000 & 989.000 & 1.273 .000 \\
\hline c. Biaya Transportasi & $\operatorname{Rp} 24.790 .000$ & $\operatorname{Rp} 25.970 .000$ & $\operatorname{Rp} \quad 26.070 .000$ \\
\hline d Biaya Pemeliharaan & $\operatorname{Rp} 12.500 .000$ & $\operatorname{Rp} 13.980 .000$ & $\operatorname{Rp} 14.044 .000$ \\
\hline e Biaya Lain-lain & $\operatorname{Rp} \quad 4.950 .000$ & $\operatorname{Rp} \quad 5.165 .000$ & 5.363 .090 \\
\hline f. Biaya Hutang & $\operatorname{Rp} \quad 8.500 .000$ & $\operatorname{Rp} 10.500 .000$ & $\operatorname{Rp} \quad 11.680 .000$ \\
\hline g. Biaya Gaji Produksi & $\operatorname{Rp} 98.890 .000$ & $\operatorname{Rp} 106.580 .000$ & $\operatorname{Rp} 114.436 .640$ \\
\hline h. Biaya Makan & $\operatorname{Rp} 7.500 .000$ & 7.980 .000 & 8.316 .000 \\
\hline 2. $\quad$ Biaya Produksi & & & \\
\hline a. Biaya Pembelian Alat (BBB) & $\operatorname{Rp} 14.560 .000$ & $\operatorname{Rp} 19.950 .000$ & $\operatorname{Rp} 19.19$ \\
\hline b. Biaya Bahan Baku & $\operatorname{Rp} 7.890 .000$ & $\operatorname{Rp} \quad 9.890 .900$ & $\operatorname{Rp} 10.271 .000$ \\
\hline c. Biaya Distribusi & 150.000 & 180.000 & 200.000 \\
\hline d. Biaya Telepon dan Listrik & $\operatorname{Rp} \quad 2.150 .000$ & $\operatorname{Rp} \quad 2.350 .000$ & $\operatorname{Rp} \quad 2.450 .000$ \\
\hline Total & Rp183.770.000 & Rp204.534.900 & Rp214.298.680 \\
\hline
\end{tabular}

Sumber : Rumah Makan Sederhana. Data diolah

Fenomena yang terjadi di Rumah Makan Sederhana yakni dari tahun 2017, 2018, dan 2019 biaya-biaya yang dikeluarkan mengalami kenaikan data ini dapat dilihat dari tabel diatas.

Hal inilah yang melatar belakangi penulis untuk pengambilan judul tentang Break Even Point, karena dengan menggunakan analisis ini kita dapat mengetahui bagaimana perencanaan laba untuk masa yang akan datang, agar perusahaan tidak mengalami penurunan laba yang sangat drastis seperti yang dialami Rumah Makan Sederhana pada tahun 2019. Karena hubungan titik impas dengan perencanaan laba ini sama-sama berbicara dalam hal anggaran atau didalamnya mencakup anggaran yang meliputi biaya, harga produk, dan volume penjualan, yang kesemua itu mengarah ke perolehan laba. Selain itu analisa titik impas dapat dijadikan tolak ukur untuk menaikkan laba atau untuk mengetahui penurunan laba yang tidak mengakibatkan kerugian pada perusahaan. Dari masalah yang telah penulis kemukakan diatas maka penulis tertarik untuk mengangkat judul penelitian yakni " Analisis Break Even Point Sebagai dasar Perencanaan Laba pada Rumah Makan Sederhana

\section{Laporan Keuangan}

\section{TINJAUAN PUSTAKA}

Laporan keuangan merupakan laporan yang memuat informasi mengenai posisi keuangan, kinerja keuangan dan arus kas entitas yang bermanfaat bagi sebagian besar kalangan pengguna laporan dalam pembuatan keputusan ekonomi. Dalam Statement Of Financial Accounting Concept (SFAC) No. 06, Financial Accounting Standards Board (FASB) telah mendefinisikan 10 unsur laporan keuangan yang berhubungan langsung dengan posisi keuangan dan hasil kerja perusahaan. Unsur-unsur inilah yang nantinya akan membentuk struktur sebuah laporan keuangan. Berikut ini adalah definisi dari masingmasing unsur laporan keuangan sebagaiman yang telah diumumkan FASB. 


\section{Laporan Laba Rugi}

Commite on Termonology mendefinisikan laba sebagai jumlah yang berasal dari pengurangan harga pokok produksi, biaya lain, dan kerugian dari penghasilan atau penghasilan operasi.Menurut Accounting Principles Board (APB) Statement mengartikan laba/rugi sebagai kelebihan atau defisit pengahsilan diatas biaya selama satu periode akuntansi.

FASB Statement mendefenisikan Accounting Income atau laba akuntansi sebagai perubahan dalam equity (net aset) dari suatu entity selama suatu periode tertentu yang diakibatkan oleh transaksi dan kejadian atau peristiwa yang berasal dari bukan pemilik. Dalam Income termasuk seluruh perubahan dalam equity selain dari pemilik dan pembayaran kepada pemilik.

Laporan laba meringkaskan hasil dari kegiatan perusahaan yang selama periode akuntansi tertentu. Laporan ini sering dipandang sebagai laporan akuntansi yang paling penting dalam laporan tahunan. Kegiatan perusahaan selama periode tertentu mencakup aktivitas rutin atau operasional, disamping aktivitas-aktivitas yang sifatnya tak rutin dan jarang muncul. Disamping itu perusahaan mungkin memutuskan untyk menghentikan lini bisnis tertentu, melakukan perubahan metode akuntansi, melaporkan item-item luar biasa. Aktivitas-aktivitas ini perlu dilaporkan dengan semestinya agar pembaca laporan keuangan memperoleh informasi yang relevan.

Nampaknya komponen dari laba bersih lebih penting dibandingkan dengan jumlah total laba bersih sebagai bahan informasi untuk tujuan analisis seperti yang disebutkan dimuka. Konsekuensinya, komponen dari laba bersih seharusnya dilaporkan secara terpisah, apalagi apabila komponen tersebut cukup signifikan untuk menaksir pendapatan atau laba perusahaan pada masa mendatang. Komponen laba dari laba operasional, operasi yang dihentikan, item-item luar biasa, seharusnya dilaporkan secara terpisah. Begitu juga akan lebih baik apabila ada informasi yang terpisah untuk setiap segmen geografis, dan bidang industry untuk perusahaan yang bergerak pada banyak bidang industri.

\section{Akuntansi Biaya}

Biaya adalah pengorbanan sumber ekonomi, yang diukur dengan satuan uang, yang telah terjadi atau yang kemungkinan akan terjadi untuk tujuan tertentu. Ada unsur pokok dalam definisi biaya tersebut di atas:
a. Biaya merupakan pengorbanan sumber ekonomi
b. Diukur dalam satuan uang
c. Yang telah terjadi atau yang secara potensial akan terjadi
d. Pengorbanan tersebut untuk tujuan tertentu

\section{Perencanaan Laba}

Setiap keinginan untuk meningkatkan pertumbuhan perusahaan, maka harus diikuti dan dimulai dengan perencanaan yang matang serta kerja keras untuk merealisasikannya. Dalam perencanaan akan disusun hal-hal apa saja yang akan dilakukan ke depan. Perencanaan yang menghasilkan rencana, yang merupakan pedoman bagi manajemen untuk melaksanakan kegiatannya.

Oleh karena itu, setiap periode manjemen akan menyusun berbagai rencana yang berkaitan dengan aktivitas perusahaan ke depan. Penyusunan relevan didasarkan pertimbangan berbagai faktor yang akan mempengaruhinya, seperti hal-hal yang sudah dilakukan sebelumnya, baik kendala atau hambatan yang dihadapi sekarang dan masa yang akan datang.

Menurut Adi Saputro dan Anggraini mengemukakan bahwa perencanaan laba adalah gambaran keuangan yang naratif mengenai hasil yang diharapkan dari implememtasi keputusan. Istilah perencanaan laba (anggaran) digunakan karena secara eksplisit rencana 
ini menyatakan sasaran dalam kurun waktu dan hasil keuangan yang diharapkan (pengembalian investasi, laba, biaya) untuk setiap bagian perusahaan. Perencanaan laba sering digunakan sebagai dasar dalam pengambilan keputusan investasi dan penilaian kinerja manajemen suatu perusahaan untuk masa yang akan datang. Perencanaan laba atau pengganggaran mempunyai manfaat bagi perusahaan yaitu:

1. Memberikan pendekatan yang terarah dalam pemecahan permasalahan.

2. Memaksa pihak manajemen untuk secara dini mengadakan penelaahan terhadap masalah yang dihadapi dan menanamkan kebiasaan pada organisasi untuk mengadakan telaah yang seksama sebelum mengambil suatu keputusan.

3. Menciptakan suasana organisasi yang mengarah pada pencapaian laba.

4. Merangsang peran serta dan mengkoordinasi rencana operasi berbagai segmen dari keseluruhan organisasi manajemen sehingga keputusan akhir dan rencana saling berkaitan.

5. Menawarkan kesempatan untuk menilai secara sistematik setiap segi atau aspek organisasi maupun untuk memriksa serta memperbaharui kebijakan dan pedoman dasar secara berkala.

Untuk menghitung perencanaan laba dapat di dekati dengan cara:

Perencanaan laba $=(\mathrm{Q}-\mathrm{Q}$ BEP $)(\mathrm{P}-$ biaya variabel per unit $)$

\section{Analisis Biaya Volume Laba}

Analisis biaya-volume-laba merupakan suatu metode untuk menganalisis bagaimana pengaruh keputusan operasi dan pemasaran terhadap laba berdasarkan pemahaman atas hubungan antara biaya variabel, biaya tetap, harga jual per unit, dan tingkat output.

\section{Analisis Titik Impas}

Analisis titik impas atau analisis pulang pokok atau dikenal dengan nama analisis Break Even Point (BEP) merupakan salah satu analisi keuangan yang sangat penting dalam perencanaan keuangan perusahaan. Analisis titik impas sering juga disebut analisis perencanaan laba (profit planning). Analisis ini biasanya lebih sering digunakan apabila perusahaan ingin mengeluarkan suatu produk baru. Artinya, dalam memproduksi produk baru tentu berkaitan dengan masalh biaya yang haru dikeluarkan. Kemudian penentuan harga jual serta jumlah barang atau jasa yang akan diproduksi atau dijual ke konsumen, baik dalam unit maupun rupiah.

Jumlah produksi yang akan dijual akan berkaitan erat dengan biaya yang dikeluarkan. Pada akhirnya biaya-biaya ini menjadi penentu terhadap harga jual perusahaan. Besar kecilnya biaya sangat berpengaruh terhadap harga jual, demikian pula sebaliknya. Salah satu kegunaan analisis titik impas adalah untuk menentukan biaya-biaya yang dikeluarkan dan jumlah produksi. Dengan demikian, akan dapat ditentukan diketahui berapa jumlah yang layak untuk dijalankan. Manfaat lain dari analisis titik impas untuk membantu manajer mengambil keputusan dalam hal aliran kas, jumlah permintaan (produkis), dan penentuan harga suatu produk tertentu. Intinya kegunaan dari analisis ini adalah untuk menentukan jumlah keuntungan pada berbagai tingkat penjualan.

\section{Hubungan BEP dengan Perencanaan Laba}

Analisis titik impas dengan perencanaan laba mempunyai hubungan kuat sebab analisa titik impas dan perencanaan laba sama-sama berbicara dalam hal anggaran atau di dalamnya mencakup anggaran yang meliputi biaya, harga produk, dan volume penjualan, yang kesemua itu mengarah keperolehan laba. Untuk itu dalam perencanaan perlu penerapan atau menggunakan analisa titik impas untuk perkembangan ke arah masa datang 
dan perolehan laba. Selain itu analisa titik impas dapat dijadikan tolak ukur untuk menaikkan laba atau untuk mengetahui penurunan laba yang tidak mengakibatkan kerugian pada industri.

\section{Kerangka Pemikiran}

Berhasil tidaknya suatu perusahaan pada umumnya ditandai dengan kemampuan manajemen dalam melihat kemungkinan dengan kesempatan di masa yang akan datang. Oleh sebab itu, manajemen bertugas untuk merencanakan masa depan perusahaannya. Kegiatan pokok manajemen dalam perencanaan perusahaan adalah pengambilan keputusan dalam pemilihan berbagai macam alternatif dan perumusan kebijaksanaan.

Laba yang diperoleh dalam suatu perusahan menjadi ukuran sukses atau tidaknya manajemen dalam mengelola perusahaannya. Laba dipengaruhi tiga faktor yaitu harga produk jual, biaya dan volume penjualan. Biaya menentukan harga jual untuk mencapai tingkat laba yang dikehendaki, harga jual mempengaruhi volume penjualan. Sedangkan penjualan langsung mempengaruhi volume produksi dan volume produksi mempengaruhi biaya.

\section{METODE PENELITIAN}

Penelitian ini menggunakan pendekatan kualitatif, yaitu dengan menekankan analisisnya pada proses penyimpulan komparasi serta pada analisis terhadap dinamika hubungan fenomena yang diamati dengan menggunakan logika ilmiah. Lokasi penelitianini berlokasi di rumah makan sederhana Jl. Abunawas kota kendari. Penelitian ini menggunakan data sekunder. Data sekunder yaitu data yang diperoleh secara tidak langsung dan dalam bentuk sudah jadi, baik berupa publikasi maupun data perusahaan yang dibuat oleh pihak perusahaan dengan aktivitasnya.

Teknik yang dilakukan adalah dokumentasi, yaitu dengan mengumpulkan data berupa dokumen-dokumen yakni laporan keuangan perusahaan untuk tahun 2017-2019. Data yang digunakan dalam penelitian adalah data kuantitatif, yaitu data yang disajikan dalam berbentuk angka. Kemudian dalam metode ini menggunakan analisis break even point yang bertujuan untuk mengetahui hubungan antara penjualan, biaya dan laba. Dalam penelitian ini terdapat satu variabel yang akan diteliti yaitu break even point sebagai perencanaan laba. Break Even Point sebagai perencanaan laba adalah suatu dasar untuk menentukan tingkat penjualan yang diperlukan untuk menutupi semua biaya yang terjadi agar perusahaan tidak mengalami kerugian dan tidak juga memperoleh laba agar mencapai tingkat laba yang direncanakan. Dengan kata lain, suatu usaha dikatakan impas jika jumlah penjualan (revenues) sama dengan jumlah biaya, atau apabila laba kontribusi hanya dapat digunakan untuk menutup biaya tetap saja.

\section{HASIL DAN PEMBAHASAN}

\section{Penjualan yang harus dipertahankan RM. Sederhana agar tidak mengalami kerugian pada tahun 2017, 2018 dan 2019}

Berdasarkan analisis titik impas (Break even Point), penjualan yang harus pertahankan untuk tahun 2017, 2018, dan 2019 dapat dijelaskan sebagai berikut:

a. Penjualan 2017

Berdasarkan analisis titik impas, penjualan yang harus di pertahankan oleh RM. Sederhana agar tidak mengalami kerugian pada tahun 2017 adalah sebesar Rp169.170.212 dengan jumlah produksi sebesar 6.758 porsi. Sedangkan dalam analisis margin of safety, batas jarak maksimum penurunan pendapatn penjualan perusahaan agar tidak menderita kerugian adalah sebesar 60\% dari total pendapatan yang ada atau sekitar Rp 252.450.000.

b. Penjualan 2018 
Berdasarkan analisis titik impas, penjualan yang harus di pertahankan oleh RM. Sederhana agar tidak mengalami kerugian pada tahun 2018 adalah sebesar Rp186.122.580,dengan jumlah produksi sebesar 7.367 porsi. Sedangkan dalam analisis margin of safety, batas jarak maksimum penurunan pendapatn penjualan perusahaan agar tidak menderita kerugian adalah sebesar 62\% dari total pendapatan yang ada atau sekitar Rp 307.507.600.

c. Penjualan 2019

Berdasarkan analisis titik impas, penjualan yang harus di pertahankan oleh RM. Sederhana agar tidak mengalami kerugian pada tahun 2019 adalah sebesar Rp198.024.706,dengan jumlah produksi sebesar 7.855 porsi. Sedangkan dalam analisis margin of safety, batas jarak maksimum penurunanpendapatn penjualan perusahaan agar tidak menderita kerugian adalah sebesar 55\% dari total pendapatan yang ada atau sekitar Rp 244.250.462,5.

\section{Target penjualan RM. Sederhana 2017, 2018 dan 2019}

Pada tahun 2017 perusahaan telah menargetkan penjualan sebesar Rp421.276.596, namun penjualan yang didapatkan oleh perusahaan untuk tahun2017 tersebut masih kurang yaitu sebesar Rp420.750.000 dari yang telah ditargetkan. Untuk tahun 2018 perusahaan telah menargetkan penjualan sebesar Rp498.504.409, namun penjualan yang didapatkan oleh perusahaan untuk tahun 2018 tersebut masih kurang juga dari yang telah ditargetkan dari tahun 2018 tersebut yang mana pada tahun 2018 hanya memperoleh penjualan sebesar Rp 495.980.000. sedangkan pada tahun 2019 penjualan juga masih kurang dari penjualan 2018 yang hanya sebesar Rp444..091.750, untuk itu perusahaan harus mengusahakan penjualannya lebih meningkat.Target penjualan RM. Sederhana tahun 2019 adalah sebesar Rp447.799.783.

\section{Estimasi perencanaan laba tahun 2018 dan 2019}

Pada tahun 2018 penulis mengestimasi adanya peningkatan laba perusahaan sebesar $25 \%$ dari laba tahun 2019. Hal ini didukung beberapa faktor seperti peningkatan daya minat dan daya beli masyarakat terhadap produk dari rumah makan sederhana. Selain itu produk yang memiliki nilai ekonomis yang tinggi dan juga didukung strategi pemasaran yang bagus. Sementara jika dilihat dari analisis titik impas dalam mencapai peningkatan laba tersebut perusahaan harus melakukan penjualan sebesar 81.823 porsi agar tidak menderita kerugian. Dari estimasi penjualan sebesar Rp555.114.687. Dan pada tahun 2019 penulis mengestimasikan peningkatan laba sebesar 50\% dari laba tahun 2019. Terjadi peningkatan estimasi dari 25\% menjadi 50\% dimana berdasarkan perusahaan akan mengalami peningkatan permintaan dari konsumen. Sementara jika dilihat dari analisis titik impas dalam mencapai peningkatan laba tersebut perusahaan harus melakukan penjualan sebesar 122.742 porsi agar tidak menderita kerugian.

\section{Pembahasan}

a) Biaya Tetap Total

Biaya tetap terdiri dari depresiasi, biaya gaji dan biaya lain-lain. Tabel di bawah ini menggambarkan biaya tetap tahun anggaran 2017, 2018, dan 2019.

\section{Tabel 4.2}

\section{Anggaran Biaya Tetap Tahun 2017, 2018 dan 2019}

\begin{tabular}{|c|c|c|c|}
\hline Jenis Biaya & $\begin{array}{l}2017 \\
(\mathrm{Rp})\end{array}$ & $\begin{array}{l}2018 \\
\text { (Rp) }\end{array}$ & $\begin{array}{l}2019 \\
(\mathrm{Rp})\end{array}$ \\
\hline $\begin{aligned} & \text { 1. } \text { Biaya gaji } \\
& \text { administrasi } \\
& \text { 2. } \text { Biaya alat } \\
& \text { tulis kantor } \\
& \text { 3. Biaya } \\
& \text { transportasi }\end{aligned}$ & $\begin{array}{l}1.000 .000 \\
890.000 \\
24.790 .000 \\
12.500 .000 \\
4.950 .000 \\
8.500 .000\end{array}$ & $\begin{array}{l}1.000 .000 \\
989.000 \\
25.970 .000 \\
13.980 .000 \\
5.165 .000 \\
10.500 .000\end{array}$ & $\begin{array}{l}1.000 .000 \\
1.273 .000 \\
26.070 .000 \\
14.044 .000 \\
5.363 .090 \\
11.680 .000\end{array}$ \\
\hline
\end{tabular}


Jurnal Akuntansi dan Keuangan (JAK)

Volume 6, No. 1 Februari Tahun 2021

Page: $56-73$

http://ojs.uho.ac.id/index.php/jak-uho/issue/archive

e-ISSN: 2088-4656

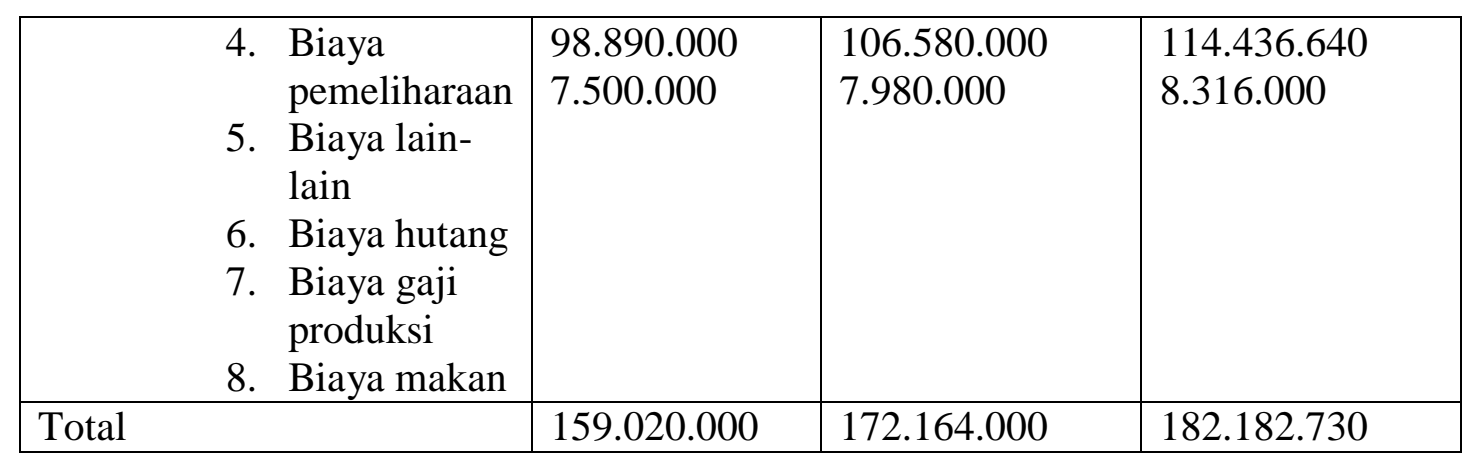

Sumber : RM. Sederhana

b) Biaya Variabel

Biaya variabel terdiri dari biaya bahan baku, biaya bahan penolong, biaya distribusi dan biaya telepon dan listrik. Tabel di bawah ini menggambarkan biaya variabek tahun anggaran 2017, 2018, dan 2019.

Tabel 4.3

Anggaran Biaya Variabel 2017, 2018 dan 2019

\begin{tabular}{|c|c|c|c|}
\hline Jenis Biaya & $\begin{array}{l}2017 \\
(\mathrm{Rp})\end{array}$ & $\begin{array}{l}2018 \\
(\mathrm{Rp})\end{array}$ & $\begin{array}{l}2019 \\
(\mathrm{Rp})\end{array}$ \\
\hline $\begin{array}{l}\text { 1. Biaya pembelian } \\
\text { alat (biaya bahan } \\
\text { baku) } \\
\text { 2. Biaya bahan } \\
\text { pendukung } \\
\text { 3. Biaya distribusi } \\
\text { 4. Biaya telepon \& } \\
\text { listrik }\end{array}$ & $\begin{array}{l}14.560 .000 \\
7.890 .000 \\
150.000 \\
2.150 .000\end{array}$ & $\begin{array}{l}19.950 .000 \\
9.890 .900 \\
180.000 \\
2.350 .000\end{array}$ & $\begin{array}{l}19.194 .950 \\
10.271 .000 \\
200.000 \\
2.450 .090\end{array}$ \\
\hline Total & 24.750 .000 & 32.370 .900 & 32.115 .950 \\
\hline
\end{tabular}

Sumber : RM. Sederhana Kendari

Adapun biaya variabel per unit dapat dihitung dengan menggunakan rumus sebagai berikut:

Biaya variabel perporsi $=\frac{\text { Total biaya } \text { variabel }}{\text { Kuantiti }}$

kuantiti $=\frac{\text { Pendapatan }}{\text { Harga jual perunit }}$

kuantiti $2017=\frac{420.750 .000}{25.000}=16.830$

kuantiti $2018=\frac{495.980 .000}{25.000}=19.839$

kuantiti $2019=\frac{444.091 .750}{25.000}=17.763$

Biaya variabel per porsi $2017=\frac{24.750 .000}{16.830}=1.470$

Biaya variabel per porsi $2018=\frac{32.370 .900}{19.839}=1.631$

Biaya variabel per porsi $2019=\frac{32.115 .950}{17.763}=1.808$ 
Jurnal Akuntansi dan Keuangan (JAK)

Volume 6, No. 1 Februari Tahun 2021

Page: $56-73$

http://ojs.uho.ac.id/index.php/iak-uho/issue/archive

Tabel 4.4

Laporan Anggaran Laba Kontribusi Tahun 2017

\begin{tabular}{|l|l|}
\hline & Penjualan RM. Sederhana \\
\hline Penjualan & 420.750 .000 \\
Biaya Variabel & 24.750 .000 \\
Margin Kontribusi & 396.000 .000 \\
Biaya Tetap & 159.020 .000 \\
Laba Bersih & 236.980 .000 \\
\hline
\end{tabular}

Sumber : RM. Sederhana Kendari

Ratio Contribution Margin (RCM) tahun 2017 dapat dihitung sebagai berikut:

Rasio Margin Kontribusi $=\frac{\text { Margin Kontribusi }}{\text { Penjualan }} \times 100 \%$

Rasio Margin Kontribusi $=\frac{396.000 .000}{420.750 .000} \times 100 \%=94 \%$

Tabel 4.5

Laporan Anggaran Laba Kontribusi Tahun 2018

\begin{tabular}{|l|l|}
\hline & Penjualan RM. Sederhana \\
\hline Penjualan & 495.980 .000 \\
Biaya Variabel & 32.370 .900 \\
Margin Kontribusi & 463.609 .100 \\
Biaya Tetap & 172.164 .000 \\
Laba Bersih & 291.445 .100 \\
\hline
\end{tabular}

Sumber : RM. Sederhana Kendari

Ratio Contribution Margin (RCM) tahun 2018 dapat dihitung sebagai berikut:

Rasio Margin Kontribusi $=\frac{\text { Margin Kontribusi }}{\text { Penjualan }} \times 100 \%$

Rasio Margin Kontribusi $=\frac{463.609 .100}{495.980 .000} \times 100 \%=93 \%$

Tabel 4.6

Laporan Anggaran Laba Kontribusi Tahun 2017

\begin{tabular}{|l|l|}
\hline & Penjualan RM. Sederhana \\
\hline Penjualan & 444.091 .750 \\
Biaya Variabel & 32.115 .950 \\
Margin Kontribusi & 411.975 .800 \\
Biaya Tetap & 182.182 .730 \\
Laba Bersih & 229.793 .070 \\
\hline
\end{tabular}

Sumber : RM. Sederhana Kendari

Ratio Contribution Margin (RCM) tahun 2019 dapat dihitung sebagai berikut:

Rasio Margin Kontribusi $=\frac{\text { Margin Kontribusi }}{\text { Penjualan }} \times 100 \%$

Rasio Margin Kontribusi $=\frac{411.975 .800}{444.091 .750} \times 100 \%=92 \%$

Ratio Contribution Margin (RCM) sangat penting dalam menentukan kebijakan bisnis, karena menunjukkan bagaimana contribution margin akan dipengaruhi oleh total penjualan. Tahun 2017 RM. Sederhana memiliki Ratio Contribution Margin (RCM) 94\%. Hal ini berarti bahwa RM. Sederhana merencakan peningkatan penjualan sebesar Rp.420.750.000 Untuk tahun 2017, manajemen dapat menentukan contribution margin sebesar Rp. Dan memperoleh laba sebesar Rp.396.000.000. 
Tahun 2018 RM. Sederhana memiliki Ratio Contribution Margin (RCM) 93\%. Hal ini berarti bahwa RM. Sederhana merencakan peningkatan penjualan sebesar Rp495.980.000. Untuk tahun 2017, manajemen dapat menentukan contribution margin sebesar Rp. Dan memperoleh laba sebesar Rp.463.609.100

Tahun 2019 RM. Sederhana memiliki Ratio Contribution Margin (RCM) . Hal ini berarti bahwa RM. Sederhana merencakan peningkatan penjualan sebesar Rp444.091.750. Untuk tahun 2017, manajemen dapat menentukan contribution margin sebesar Rp. Dan memperoleh laba sebesar Rp.411.975.800

\section{Titik Impas atau Break Even Point (BEP)}

a. Break Even Point (BEP) tahun 2017 adalah:

$\mathrm{BEP}=\frac{\text { Biaya tetap }}{\text { RCM }}$

$\mathrm{BEP}=\frac{159.020 .000}{94 \%}=$ Rp. 169.170 .212

BEP porsi $=\frac{\text { Biaya Tetap }}{\text { Harga Jual per Unit-Biaya Variabel per Unit }}$

BEP porsi $=\frac{159.020 .000}{25.000-1.470}=6.758$ porsi

b. Break Even Point (BEP) total tahun 2018 adalah:

$\mathrm{BEP}=\frac{\text { Biaya tetap }}{\text { RCM }}$

$\mathrm{BEP}=\frac{172.164 .000}{93 \%}=\mathrm{Rp} .185 .122 .580,64$

BEP porsi $=\frac{\text { Biaya Tetap }}{\text { Harga Jual per Unit-Biaya Variabel per Unit }}$

BEP porsi $=\frac{172.164 .0000}{25.000-1.631}=7.367$ porsi

c. Break Even Point (BEP) total tahun 2019 adalah:

$\mathrm{BEP}=\frac{\text { Biaya tetap }}{\text { RCM }}$

$\mathrm{BEP}=\frac{182.182 .730}{92 \%}=\mathrm{Rp} .198 .024 .706,52$

BEP porsi $=\frac{\text { Biaya Tetap }}{\text { Harga Jual per Unit-Biaya Variabel per Unit }}$

$\mathrm{BEP}$ porsi $=\frac{182.182 .730}{25.000-1.808}=7.855$ porsi

Break Even Point (BEP) menunjukkan penjualan perusahaan tidak mendapatkan laba dan tidak mendapatkan rugi. Pada tahun 2017 BEP dalam rupiah RM. Sederhana sebesar Rp.169.170.212,176, dan BEP per Unit adalah 6.758 yang berarti bahwa pada tahun 2017, perusahaan mampu menutupi seluruh biaya tersebut untuk mencapai impas.

Tahun 2018 BEP dalam rupiah RM. Sederhana sebesar Rp.185.122.580,64 dan BEP per Unit adalah 7.367 yang berarti bahwa pada tahun 2017, perusahaan mampu menutupi seluruh biaya tersebut untuk mencapai impas.

Tahun 2019 BEP dalam rupiah RM. Sederhana sebesar Rp.198.024.706,52 dan BEP per Unit sebesar 7.855 yang berarti bahwa pada tahun 2017, perusahaan mampu menutupi seluruh biaya tersebut untuk mencapai impas.

\section{Margins of Safety (MOS)}

a) Margins of safety (MOS) total tahun 2017 dapat dihitung sebagai berikut:

Margins of Safety $($ MOS $)=\frac{\text { Sales Budgeted }- \text { Sales at Break Even }}{\text { Sales Budgeted }} \times 100 \%$

MOS dalam rupiah $=$ MOS X Sales Budgeted

MOS $=\frac{420.750 .000-169.170 .212,176}{420.750 .000} \times 100 \%=60 \%$

MOS dalam rupiah $=60 \% \times 420.750 .000=252.450 .000$

b) Margins of safety (MOS) total tahun 2018 dapat dihitung sebagai berikut: 
Margins of safety $(\mathrm{MOS})=\frac{\text { Sales Budgeted-Sales at Break Even }}{\text { Sales Budgeted }} \times 100 \%$

MOS dalam rupiah $=$ MOS X Sales Budgeted

MOS $=\frac{495.980 .000-186.122 .580,64}{495.980 .000} \times 100 \%=62 \%$

MOS dalam rupiah $=62 \% \times 495.980 .000=307.507 .600$

c) Margins of safety (MOS) total tahun 2019 dapat dihitung sebagai berikut:

Margins of safety $(\mathrm{MOS})=\frac{\text { Sales Budgeted-Sales at Break Even }}{\text { Sales Budgeted }} \times 100 \%$

MOS dalam rupiah $=$ MOS X Sales Budgeted

$\mathrm{MOS}=\frac{444.091 .750-198.024 .706,52}{444.091 .750} \times 100 \%=55 \%$

MOS dalam rupiah $=55 \% \times 444.091 .750=244.250 .462,5$

Margins of Society (MOS) menunjukkan jarak antara penjualan yang direncanakan dengan penjualan pada titik impas. Dengan demikian margin of safety juga menggambarkan batas jarak, dimana kalau berkurangnya penjualan melampaui batas jarak tersebut perusahaan akan menderi takerugian. Dari hasil perhitungan di atas diperoleh tingkat margin of safety tahun 2017 sebesar 60\% yang berarti bahwa pada tingkat penjualan dan struktur biaya yang ada, jumlah maksimum penurunan target pendapatan penjualan yang tidak menyebabkan perusahaan mengalami kerugian adalah Rp. 252.450.000.

Margin of safety tahun 2018 mengalami kenaikan dari tahun sebelumnya, yaitu dari $60 \%$ menjadi $62 \%$. Jumlah maksimum kenaikan target pendapatan penjualan yang tidak menyebabkan perusahaan mengalami kerugian adalah Rp. 252.450.000.(Tahun 2017). Kenaikan yang terjadi tidaklah banyak namun tetap harus tetap diperhatikan. Margin of Safety pada tahun 2018 sebesar $62 \%$ yang berarti bahwa pada tingkat penjualan dan struktur biaya yang ada, jumlah maksimum penurunan target pendapatan penjualan yang tidak menyebabkan perusahaan mengalami kerugian adalah Rp. 307.507.600.

Margin of safety tahun 2019 mengalami penurunan dari tahun sebelumnya, yaitu dari $62 \%$ menjadi $55 \%$. Jumlah maksimum penurunan target pendapatan penjualan yang tidak menyebabkan perusahaan mengalami kerugian adalah Rp. 244.250.462,5.

Semakin tinggi margin of safety suatu perusahaan dikatakan semakin baik karena rentang penurunan penjualan yang dapat ditolerir adalah lebih besar sehingga kemungkinan menderita kerugian rendah. Semakin kecil margin of safety berarti semakin cepat perusahaan menderita kerugian, dalam hal ini terdapat penurunan jumlah penjualan yang nyata.

\section{Target penjualan 2017,2018 dan 2019}

Untuk menentukan tingkat penjualan yang dibutuhkan agar mencapai tingkat laba yang diharapkan. Mencari laba yang diharapkan meliputi perencanaan pendapatan. Perencanaan pendapatan menentukan pendapatan yang dibutuhkan agar mencapai tingkat laba yang diharapkan lebih terkendali, maka dapat dihitung target laba yang dibutuhkan.

a) Target penjualan tahun $2017=\frac{\text { biaya tetap+laba }}{\text { contribusi margin ratio }}$

$$
\begin{aligned}
& =\frac{159.020 .000+236.980 .000}{94 \%} \\
& =R p 421.276 .596
\end{aligned}
$$

Dalam menargetkan penjualan yang akan diperoleh perusahaan untuk tahun 2017 perusahaan telah menargetkan penjualan sebesar Rp421.276.596, namun penjualan yang didapatkan oleh perusahaan untuk tahun 2017 tersebut masih kurang dari yang telah ditargetkan, target penjualan ini menjadi acuan bagi perusahaan untuk target penjualan 2018. Penjualan yang didaptakan tahun 2018 sebesar Rp 495.080.000 hal ini telah melebihi target yang telah dibuat untuk tahun 2017. 
Jurnal Akuntansi dan Keuangan (JAK)

Volume 6, No. 1 Februari Tahun 2021

Page: $56-73$

http://ojs.uho.ac.id/index.php/iak-uho/issue/archive

e-ISSN: 2088-4656

b) Target penjualan tahun $2018=\frac{\text { biaya tetap+laba }}{\text { contribusi margin ratio }}$

$$
\begin{aligned}
& =\frac{172.164 .000+291.445 .100}{93 \%} \\
& =R p 498.504 .409
\end{aligned}
$$

Untuk tahun 2018 perusahaan telah menargetkan penjualan sebesar Rp498.504.409, namun penjualan yang didapatkan oleh perusahaan untuk tahun 2018 tersebut masih kurang juga dari yang telah ditargetkan dari tahun 2018 tersebut yang mana pada tahun 2018 hanya memperoleh penjualan sebesar Rp 495.980.000. sedangkan pada tahun 2019 penjualan juga masih kurang dari penjualan 2018 yang hanya sebesar Rp444..091.750, untuk itu perusahaan harus mengusahakan penjualannya lebih meningkat.

c) Target penjualan tahun $2019=\frac{\text { biaya tetap+laba }}{\text { contribusi margin ratio }}$

$$
=\frac{182.182 .730+229.793 .070}{92 \%}=R p 447.799 .783
$$

Target penjualan RM. Sederhana tahun 2019 adalah sebesar $R p 447.799 .783$, angka ini juga masih kurang dari penjualan pada tahun 2019 ini hanya memperoleh penjualan sebesar Rp444.091.750. sedangkan perusahaan menargetkan penjualan melebihi angka tersebut.

4. Perencanaan laba tahun 2020 dan 2021

Berdasarkan laporan anggaran laba kontribusi tahun 2019 maka dapat dilakukan perencanaan laba pada tahun yang mendatang. Dalama hal ini penulis akan merencanakan laba RM. Sederhana pada tahun 2020 dan 2021. Perencanaan yang dilakukan berupa perhitungan estimasi dari penulis untuk perolehan laba di tahun 2020 dan 2021.

Pada tahun 2020 penulis mengestimasi perencanaan anggaran penjualan meningkat 25\% dari laporan anggaran laba konstribusi RM. Sederhana tahun 2019 sebagai berikut:

\section{Tabel 4.7}

\section{Laporan Anggaran Laba Kontribusi Tahun 2020 Naik 25\%}

\begin{tabular}{|l|l|}
\hline & Penjualan RM. Sederhana \\
\hline Penjualan & 555.114 .687 \\
Biaya Variabel & 40.144 .937 \\
Margin Kontribusi & 514.969 .750 \\
Biaya Tetap & 227.728 .412 \\
Laba Bersih & 287.241 .338 \\
\hline
\end{tabular}

Biaya variabel per $\mathrm{kg}=\frac{\text { total biaya variabel }}{\text { kuantiti }}$

Kuantiti

$$
=\frac{\text { pendapatan }}{\text { harga jual per unit }}
$$

Biaya variabel per porsi $20120=\frac{40.144 .937}{22.204}=1.808$

Kuantiti $2020=\frac{555.114 .687}{25.000}=22.204$

Ratio Contribution Margin (RCM) tahun 2020 dapat dihitung sebagai berikut:

Rasio Margin Kontribusi $=\frac{\text { Margin Kontribusi }}{\text { Penjualan }} \times 100 \%$

Rasio Margin Kontribusi $=\frac{514.969 .750}{555.114 .687} \times 100 \%=92 \%$

Untuk tahun 2021, penulis mengestimasi perencanaan anggaran penjualan meningkat 50\% dari laporan anggaran laba konstribusi RM. Sederhana tahun 2020 dikarenakan peneliti melihat beberapa faktor pendukung yang diantaranya yakni: 
Jurnal Akuntansi dan Keuangan (JAK)

Volume 6, No. 1 Februari Tahun 2021

Page: $56-73$

http://ojs.uho.ac.id/index.php/iak-uho/issue/archive

e-ISSN: 2088-4656

a) Makan yang dibuat tidak kalah enak dibanding makanan yang dibuat oleh resto atau warung makan yang lainnya.

b) Harga yang ditawarkan cukup murah bisa dijangkau semua kalangan masyarakat. Berdasarkan faktor-faktor tersebut sehingga peneliti dapat mengestimasi perencanaan laba perusahaan di tahun 2021 meningkat menjadi 50\% sebagai berikut:

\section{Tabel 4.8}

Laporan Anggaran Laba Kontribusi Tahun 2021 Naik 50\%

\begin{tabular}{|l|l|}
\hline & Penjualan RM. Sederhana \\
\hline Penjualan & 832.672 .030 \\
Biaya Variabel & 60.217 .405 \\
Margin Kontribusi & 772.454 .625 \\
Biaya Tetap & 341.592 .618 \\
Laba Bersih & 430.862 .007 \\
\hline
\end{tabular}

Biaya variabel per porsi $=\frac{\text { total biaya variabel }}{\text { kuantiti }}$

kuantiti $=\frac{\text { pendapatan }}{\text { harga jual per unit }}$

Biaya variabel per porsi $=\frac{60.217 .405}{33.306}=1.808$

kuantiti $=\frac{832.672 .030}{25.000}=33.307$

Ratio Contribution Margin (RCM) tahun 2021 dapat dihitung sebagai berikut:

Rasio Margin Kontribusi $=\frac{\text { Margin Kontribusi }}{\text { Penjualan }} \times 100 \%$

Rasio Margin Kontribusi $=\frac{772.454 .625}{832.672 .030} \times 100 \%=93 \%$

Tahun 2020 RM. Sederhana memiliki Ratio Contribution merencakan peningkatan penjualan sebesar Rp.555.114.687.

Tahun 2021 RM. Sederhana memiliki Ratio Contribution Margin (RCM) 93\%. Hal ini berarti bahwa RM. Sederhana merencakan peningkatan penjualan sebesar Rp. 832.672.030

1) Titik Impas atau Break Even Point (BEP) dan Perencanaan Laba

a) Break Even Point (BEP) tahun 2020 adalah:

$\mathrm{BEP}=\frac{\text { Biaya Tetap }}{\mathrm{RCM}}$

$\mathrm{BEP}=\frac{227.728 .412}{92 \%}=$ Rp. 247.530 .882

BEP porsi $=\frac{\text { Biaya Tetap }}{\text { Harga jual perunit-Biaya Variabel per unit }}$

BEP porsi $=\frac{227.728 .412}{25.000-1.808}=9.819$ porsi

Perencanaan laba tahun 2020:

Perencanaan laba $=\left(\mathrm{Q}-\mathrm{Q}_{\mathrm{BEP}}\right)(\mathrm{P}-$ biaya variabel per unit $)$

287.241.338 $=(\mathrm{Q}-9.819)(25.000-1.808)$

$287.241 .338=(\mathrm{Q}-9.819)(23.192)$

$287.241 .338=23.192 Q-227.722 .248$

$\mathrm{Q} \quad=\frac{514.963 .586}{23.192}$

$\mathrm{Q} \quad=22.204$ porsi

b) Break Even Point (BEP) total tahun 2021 adalah:

$$
\mathrm{BEP}=\frac{\text { Biaya Tetap }}{\text { RCM }}
$$


Jurnal Akuntansi dan Keuangan (JAK)

Volume 6, No. 1 Februari Tahun 2021

Page: $56-73$

http://ojs.uho.ac.id/index.php/iak-uho/issue/archive

e-ISSN: 2088-4656

$$
\begin{aligned}
& \mathrm{BEP}=\frac{341.592 .618}{93 \%}=\mathrm{Rp} .367 .303 .890 \\
& \text { BEP porsi }=\frac{\text { Biaya Tetap }}{\text { Harga jual per unit-biaya variabel per unit }} \\
& \begin{array}{ll}
\text { BEP porsi }==\frac{341.592 .618}{25.000--1.808}=14.729 \text { porsi } \\
\text { Perencanaan laba tahun } 2019: \\
\text { Perencanaan laba } & =\left(\mathrm{Q}-\mathrm{Q}_{\mathrm{BEP}}\right)(\mathrm{P}-\text { biaya variabel per unit }) \\
430.862 .007 & =(\mathrm{Q}-14.729)(25.000-1.808) \\
430.862 .007 & =(\mathrm{Q}-14.729)(23.192) \\
430.862 .007 & =23.192 \mathrm{Q}-341.594 .968 \\
\mathrm{Q} & =\frac{772.456 .975}{23.192} 772.452 .9932783 \\
\mathrm{Q} & =33.307 \text { porsi }
\end{array}
\end{aligned}
$$

Pada tahun 2020 BEP dalam rupiah RM. Sederhana sebesar Rp.247.530.882 dan BEP unit nya 9.819, yang berarti bahwa pada tahun 2020, perusahaan mampu menutupi seluruh biaya tersebut untuk mencapai impas. Untuk mendapatkan proyeksi laba tahun 2020 sebesar Rp287.241.338 RM. Sederhana harus mmeproduksi sebanyak 22.204 Porsi.

Tahun 2021 BEP dalam rupiah RM. Sederhana sebesar Rp.367.303.890 dan BEP unit sebesar 122.733, yang berarti bahwa pada tahun 2021, perusahaan mampu menutupi seluruh biaya tersebut untuk mencapai impas.Untuk mendapatkan proyeksi laba tahun 2019 sebesar Rp430.062.007 RM. Sederhanaharus mmeproduksi sebanyak 33.307 Porsi. 2). Margins of Sofety (MOS)

a. Margins of Sofety (MOS) total tahun 2020 dapat dihitung sebagai berikut:

Margins of Sofety $(\mathrm{MOS})=\frac{\text { Sales Budgeted-Sales at Break Even }}{\text { Sales Budgeted }} \times 100 \%$

MOS dalam rupiah $=$ MOS X Sales Budgeted

MOS $=\frac{555.114 .687-247.530 .882}{555.114 .687} \times 100 \%=55 \%$

MOS dalam rupiah $=55 \%$ x 555.114.687 $=305.313 .007$

b. Margins of safety (MOS) total tahun 2021 dapat dihitung sebagai berikut:

Margins of safety $(\mathrm{MOS})=\frac{\text { Sales Budgeted-Sales at Break Even }}{\text { Sales Budgeted }} \times 100 \%$

MOS dalam rupiah $=$ MOS X Sales Budgeted

MOS $=\frac{832.672 .030-367.303 .890}{832.672 .030} \times 100 \%=56 \%$

MOS dalam rupiah $=56 \%$ x 832.672.030 $=466.296 .336$

Dari hasil perhitungan diatas diperoleh tingkat margin keamanan taun 2020 sebesar $55 \%$ yang berarti bahwa pada tingkat penjualan dan struktur biaya yang ada, jumlah maksimum penurunan target pendapatan penjualan yang tidak menyebabkan perusahaan mengalami kerugian adalah Rp305.313.007.

Margin keamanan tahun 2021 sebesar 56\% yang berarti bahwa pada tingkat penjualan dan struktur biaya yang ada, jumlah maksimum penurunan target pendapatan penjualan yang tidak menyebabkan perusahaan mengalami kerugian adalah Rp466.296.336.

\section{Analisis Penelitian}

Titik impas dapat didefinisikan sebagai titik pada saat pendapatan penjualan cukup untuk menutup semua biaya produksi dan penjualan tetapi tidak ada laba yang diperoleh. Titik impas yang dimana perusahaan tidak mendapatakan keuntungan dan juga tidak mengalami kerugian. Titik impas yang dialami RM. Sederhana pada tahun 2017, 2018 dan 2019 yaitu pada tahun 2017 BEP dalam rupiah RM. Sederhana sebesar Rp. 169.170.212 dan BEP per porsi sebesar 6.758 yang berarti bahwa pada tahun 2017, perusahaan mampu menutupi seluruh biaya tersebut untuk mencapai impas. 
Tahun 2018 BEP dalam rupiah RM. Sederhana sebesar Rp.185.122.580,64 dan BEP per porsi sebesar 7.367 yang berarti bahwa pada tahun 2018, perusahaan mampu menutupi seluruh biaya tersebut untuk mencapai impas.

Tahun 2019 BEP dalam rupiah RM. Sederhana sebesar Rp.198.024.706,52dan BEP per porsi sebesar 7.855 yang berarti bahwa pada tahun 2019, perusahaan mampu menutupi seluruh biaya tersebut untuk mencapai impas.

Berdasarkan analisis diatas RM. Sederhana dapat mencapai titik impas walaupun disetiap tahunnya terjadi penaikan dan penurunan baik dalam segi jumlah penjualan dan volume biaya-biaya yang dikeluarkan perusahaan. Hal ini biasa dialami oleh perusahaanperusahaan dimana terjadi naik turun penjualan dan persaingan dengan perusahaanperusahaan lain yang sama jenis produk yang ditawar. Tetapi dalam hal ini perusahaan mampu menutup biaya-biaya tersebut.

Margin keamanan atau margin of safety adalah kelebihan dari penjualan yang dianggarkan diatas titik impas volume penjualan. Margin kemanaan menjelaskan jumlah dimana penjualan dapat menurun sebelum kerugian mulai terjadi. Besar margin of safety atau batas keamanan agar jumlah penjualan RM. Sederhana boleh berkurang dari rencana semula sehingga perusahaan tidak menderita rugi. Dari data BEP dan Contribution margin anggaran penjualan tahun 2017.2018 dan 2019 maka diperoleh tingkat margin of safety pada tahun 2017 sebesar 60\% yang berarti bahwa pada tingkat penjualan dan jumlah maksimum penurunan target pendapatan penjualan yang tidak menyebabkan perusahaan mengalami kerugian adalah Rp. 252.450.000.

Margin of safety pada tahun 2018 sebesar $62 \%$ yang berarti bahwa pada tingkat penjualan dan jumlah maksimum penurunan target pendapatan penjualan yang tidak menyebabkan perusahaan mengalami kerugian adalah Rp.307.507.600.

Margin of safety pada tahun 2019 sebesar 55\% yang berarti bahwa pada tingkat penjualan dan jumlah maksimum penurunan target pendapatan penjualan yang tidak menyebabkan perusahaan mengalami kerugian adalah Rp. 244.250.462,5.

Analisis diatas menganalisis dan memperhitungkan batas keamanan jumlah penjualan yang boleh berkurang dari rencana semula sehingga perusahaan tidak menderita rugi. Margin keamanan ini didapat dari perhitungan persentase hasil penjualan dikurang titik impas. Dalam margin keamanan jika perusahaan mencapai titik margin keamanan maka perusahaan masih memperoleh keuntungan.

Semakin tinggi margin of safety suatu perusahaan dikatakan semakin baik karena rentang penurunan penjualan yang dapat ditolerir adalah lebih besar sehingga kemungkinan menderita kerugian lebih rendah. Semakin kecil margin of safety berarti semakin cepat perusahaan menderita kerugian.

Untuk menentukan tingkat penjualan yang dibutuhkan agar mencapai tingkat laba yang diharapkan. Mencari laba yang diharapkan meliputi perencanaan pendapatan. Perencanaan pendapatan menentukan pendapatkan yang dibutuhkan agar mencapai tingkat laba yang diharapkan lebih terkendali. Penjualan tahun 2017-2019 masih kurang dari target penjualan yang telah dihitung maka perusahaan harus mengusahaakn penjualan dari target yang telah ditentukan, sebab dari hal tersebut kita dapat merencanakan laba yang akan diperoleh.

Peneliti juga melakukan analisis estimasi perencanaan laba pada tahun yang mendatang. Dalam penelitian ini peneliti akan mengestimasi perencanaan laba pada tahun 2020 dan 2021. Data yang menjadi dasar peneliti melakukan estimasi perencanaan ini yaitu dari data anggaran tahun 2019. Hasil analisis estimasi perencanaan laba peneliti adalah sebagai berikut: 
Pada tahun 2020 dan 2021 titik impas yang dimana perusahaan tidak mendapat keuntungan dan tidak juga mengalami kerugian yaitu 2020 BEP RM. Sederhana sebesar Rp. 247.530.882 yang berarti bahwa pada tahun 2020 perusahaan mampu menutupi seluruh biaya tersebut untuk mencapai impas.

Tahun 2021 BEP RM. Sederhana sebesar Rp. 367.303.890 yang berarti bahwa pada tahun 2021 perusahaan mampu menutupi seluruh biaya tersebut untuk mencapai impas.

Berdasarkan analisis diatas perusahaan RM. Sederhana dapat mencapai titik impas. Peneliti memperkirakan pada tahun mendatang perusahaan akan mengalami peningkatan baik dalam penjualan, volume biaya-biaya, dan laba yang meningkat.

Margin keamanan atau margin of safety menjelaskan jumlah dimana penjualan dapat menurun sebelum kerugian mulai terjadi. Dari perhitungan BEP dan Contribusi margin estimasi penjualan 2020 dan 2021 yaitu pada tahun 2020 sebesar 55\% yang berarti bahwa pada tingkat penjualan dan jumlah maksimum penurunan target pendapatan penjualan yang tidak menyebabkan perusahaan mengalami kerugian adalah $\mathrm{Rp}$. 305.313.003.

Margin keamanan tahun 2021 sebesar 56\% yang berarti bahwa pada tingkat penjualan dan jumlah maksimum penurunan target pendapatan penjualan yang tidak menyebabkan perusahaan mengalami kerugian adalah Rp. 466.296.336..

Peningkatan-peningkatan penjualan dan laba ini dikarenakan peneliti melihat kenaikan penjualan ditahun 2021 sehingga peneliti mengestimasi kenaikan penjualan yang akan dialami perusahaan pada tahun 2020 sebesar 25\% dan tahun 2021 sebesar 50\%. Hal ini dilatarbelakangi darihasil analisis ditahun 2017, 2018 dan 2019. Letak geografis perusahaan yang sangat strategis untuk mendapatkan bahan baku perusahaan. Selain itu juga minat dari para konsumen meningkat pada rumah makan.

\section{KESIMPULAN}

\section{KESIMPULAN DAN SARAN}

Dari hasil analisis yang dilakukan oleh peneliti bahwa perusahaan mampu mencapai titik impas atau mencukupi biaya-biaya pada tahun 2017, 2018 dan 2019. Titik impas ialah titik dimana total pendapatan sama dengan total biaya yang dikeluarkan perusahaan. Dimana pada tahun 2017 titik impas yang dicapai perusahaan sebesar Rp. 169.170.212,76 dan BEP per porsi sebesar 6.758 dengan total pendapatan atau penjualan sebesar Rp. 420.750.000 dan biaya tetapnya sebesar Rp. 159.020.000. Pada tahun 2018 titik impas yang dicapai perusahaan sebesar Rp. 185.122.580,64 dan BEP per porsi sebesar 7.367 dengan total penjualan sebesar Rp. 495.980.000 dan biaya tetap sebesar Rp. 172.164.000. Pada tahun 2019 titik impas yang dicapai perusahaan sebesar Rp. 198.024.706,52 dan BEP per porsi sebesar 7.855 dengan total penjualan sebesar Rp. 444.091 .750 dan biaya tetap sebesar Rp. 182.182.730.

Tahun 2020 BEP RM. Sederhana sebesar Rp. 247.530.882. Untuk mendapatkan proyeksi laba tahun 2020 sebesar Rp287.241.338 RM. Sederhana harus meproduksi sebanyak 22.204 Porsi. Tahun 2021 BEP RM. Sederhana sebesar Rp. 367.303.890 yang berarti bahwa pada tahun 2021 perusahan mampu menutupi seluruh biaya tersebut untuk mencapai impas. Untuk mendapatkan proyeksi laba tahun 2021 sebesar Rp430.062.007 RM. Sederhana harus mmeproduksi sebanyak 33.307 Porsi.

\section{SARAN}

1. Kemampuan perusahaan dalam memproduksi cukup tinggi. Hal ini. memungkinkan perusahaan untuk mengadakan perluasan usaha atau meningkatkan produksi sesuai dengan kapasitas perusahaan. Sehingga biaya tetap dapat dimanfaat sebaik-baiknya dan akan berpengaruh positif terhadap penaikan laba. 
Jurnal Akuntansi dan Keuangan (JAK)

Volume 6, No. 1 Februari Tahun 2021

Page: $56-73$

http://ojs.uho.ac.id/index.php/iak-uho/issue/archive

e-ISSN: 2088-4656

2. Meningkatkan jumlah penjualan makanan agar mendapatkan keuntungan yang diharapakan.

3. Meningkatkan jumlah pelanggan agar perusahaan dapat meningkatkan penjualan dengan pembelian cocofiber dengan jumlah yang meningkat.

4. Melakukan promosi untuk menambah tingkat penjualan RM. Sederhanadi tahun selanjutnya.

5. Saran peneliti selanjutnya agar dapat memperhitungkan perubahan-perubahan dari segi harga jual, biaya-biaya yang dikeluarkan dan perubahan volume produksi ataupun penjualan perusahaan.

\section{DAFTAR PUSTAKA}

Abdullah, Boedi. Beni Ahmad Saebani. Metode Penelitian Ekonomi Islam Muamalah. Bandung: Pustaka Setia, 2014.

Ahmad, Kamaruddin. Akuntansi Manajemen. Jakarta: Raja Grafindo Persada.2011.

Blocher, Edward J. et al, Manajemen Biaya: Penekanan Strategis. Jakarta: Salemba Empat. 2011.

Bungin, Burhan. Metodologi Penelitian Sosial Ekonomi. Jakarta: Fajar Interpratma Mandiri, 2013.

Dewi, Dian Ratna Rusmala. et al. Analisis Hubungan Margin Kontribusi sebagai Alat Bantu Perencanaan Laba pada Industri Gamelan Margolaras Kauman Magetan Periode 2014-2016. Madiun: Universitas PGRI Madiun. Vol. 5 No. 1. 2017.

Dunia, Fidaus Ahmad, Wasilah Abdullah. Akuntansi biaya. Jakarta: Salemba Empat. 2012 Garisson, Akuntansi ManajerialEdisi 14, Jakarta: Salemba Empat. 2013.

Harahap, Sofyan Syafri. Teori Akuntansi. Jakarta: Rajawali Persada. 2013. Kasmir. Analisis Laporan Keuangan. Jakarta: Rajawali Persada. 2014.

Kasmir. Pengantar Manajemen Keuangan. Jakarta: Kencana Prenada Media Group. 2010. Mulyadi. Akuntansi Biaya. Yogyakarta: UPP STIM YKPN. 2012.

Putong, Iskandar, Economics: Pengantar Mikro dan Makro, Jakarta: Mitra Wacana Media, 2013.

Samryn,L. M. Akuntansi Manajemen. Jakarta: PT Fajar Interpratama Mandiri. 2013.

Samryn,L. M. Pengantar Akuntansi 1 mudah membuat jurnal dengan pendekatan siklus transaksi. Jakarta: PT Raja Grafindo Persada. 2012.

Sorongan, Srivo Nindy. Grace B Nangoi. Analisis Titik Impas Sebagai Dasar Perencanaan Laba Jangka Pendek Produk Kacang Olahan Pada Industri Kecil Menengah di Kawangkoan. Jurnal EMBA 1647 Vol. 02 No. 2 Juni 2014. 